\title{
Determinants of the Distribution of Congressional Earmarks Across States
}

By

\author{
Melissa A. Boyle \\ and \\ Victor A. Matheson
}

May 2008

\section{COLLEGE OF THE HOLY CROSS, DEPARTMENT OF ECONOMICS \\ FACULTY RESEARCH SERIES, PAPER NO. 08-06*}

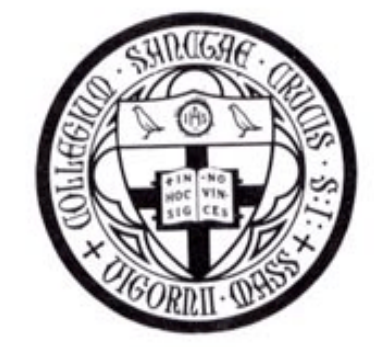

Department of Economics

College of the Holy Cross

Box 45A

Worcester, Massachusetts 01610

(508) 793-3362 (phone)

(508) 793-3710 (fax)

http://www.holycross.edu/departments/economics/website

*All papers in the Holy Cross Working Paper Series should be considered draft versions subject to future revision. Comments and suggestions are welcome. 


\title{
Determinants of the Distribution of Congressional Earmarks Across States
}

\author{
By \\ Melissa A. Boyle ${ }^{\dagger}$ \\ College of the Holy Cross \\ and \\ Victor A. Matheson ${ }^{\dagger \dagger}$ \\ College of the Holy Cross
}

May 2008

\begin{abstract}
Congressional earmarks have been the subject of significant political debate in recent years. Also known as "pork barrel spending," earmarks are budgetary requests made by a single legislator that typically circumvent the traditional competitive bidding process designed to ensure the efficient use of public dollars. Utilizing annual state-level estimates of pork barrel spending, we briefly examine the factors influencing states' receipt of earmarked funds from Congress. Results indicate that on average smaller states receive the largest amount of per capita earmarked funding, most likely as a result of their disproportionate influence in the Senate. In addition, the presence of a Republican Congressional delegation increases pork spending in the state. Finally, the tenure of a state's senior Senator has a large effect on the state's receipt of earmarked funds. Each additional year of Senate experience by a state's senior Senator results in a \$4.48 increase in earmarked dollars per capita for that state's residents.
\end{abstract}

JEL Classification Codes: D72, H50, H61

Keywords: pork barrel spending, pork, earmarks, government spending

${ }^{\dagger}$ Department of Economics, Box 191A, College of the Holy Cross, Worcester, MA 01610-2395, 508-793-2334 (phone), 508-793-3710 (fax), mboyle@ holycross.edu

${ }^{\dagger \dagger}$ Department of Economics, Box 157A, College of the Holy Cross, Worcester, MA 01610-2395, 508-793-2649 (phone), 508-793-3710 (fax), vmatheso@ holycross.edu 


\section{Introduction}

The reduction of government waste and fraud is a top goal of political reformers. One particular form of government waste that has become the subject of significant debate over the past several years is the technique known as "earmarking." Earmarks are budgetary requests made by a single legislator that typically direct spending towards his or her own constituents. Earmarks generally circumvent the traditional competitive bidding process or other controls designed to ensure that government spending meets efficiency standards. Earmarks are also commonly known as "pork barrel spending," or more simply as "pork" and the terms will be used interchangeably in this paper. The problems of earmarking are exemplified by the infamous “bridge to nowhere." In 2005, Alaska Senator Ted Stevens earmarked funds to build a bridge between the small town of Ketchikan and nearby Gravina Island at a cost to taxpayers of $\$ 320$ million, or roughly $\$ 40,000$ per resident of Ketchikan.

The elimination of wasteful government spending is often a hallmark of political campaigns. For example, 2008 Republican Presidential nominee John McCain estimated that "the savings from eliminating earmarks, reviewing federal programs and other budget reforms would be "on the order of $\$ 100$ billion annually," an amount that would fund a significant portion of the tax cuts proposed by the candidate (Cooper, 2008). McCain sponsored legislation in early 2008 that would have placed a one-year moratorium on Congressional earmarking, but the bill was soundly defeated in the Senate despite support from McCain and the two leading Democratic contenders for their party's presidential nomination, Hillary Clinton and Barack Obama. This paper briefly examines the factors that lead states to receive earmarked funding from Congress based on recent earmarking data. 
Several academic papers have focused on the distribution of federal spending across states. Alverez and Saving (1997) examine whether individual legislators can influence spending patterns to a significant degree and find "strong and systematic evidence of pork-barrel activities by committee members" on influential Congressional committees. Knight (2004) focuses on the disproportionate bargaining power of small states and finds that small states do indeed receive a statistically significant advantage in receiving federal funding in comparison with larger states, a view echoed by Hauk and Wacziarg (2007) in their examination of the 2005 Federal Highway Bill. Bernhardt, et al. (2004) theorize that incumbent politicians with seniority will be able to direct larger funding to their districts and use this notion to argue in favor of term limits for legislators.

\section{Data and Model}

There is no one simple definition of what qualifies as government pork. One person's wasteful spending is another person's important investment into the economic future of a community. This paper uses state-by-state figures for earmarks compiled by Citizens Against Government Waste (CAGW), a non-partisan taxpayer watchdog organization. Between 2000 and 2006 CAGW published an annual "Congressional Pig Book Summary" which lists projects that the organization feels "symbolize the most egregious and blatant examples of pork." (CAGW, 2006) CAGW includes budget items in the Pig Book on a case by case basis if they satisfy at least one of the following seven criteria: "1. requested by only one chamber of Congress; 2 . not specifically authorized; 3 . not competitively awarded; 4. not requested by the President; 5 . greatly exceeds the President's budget request or the previous year's funding; 6 . not the subject of congressional hearings; or 7. serves only a local or special interest." (CAGW, 2006) Other 
organizations also publish lists of pork barrel spending and Congressional earmarks that are slightly different than those published by CAGW, but overall, most lists of pork spending are broadly similar. The annual summary statistics for the data are shown in Table 1.

The model for estimating earmarks by state is shown in equation 1

$$
k_{t i}=\gamma+\alpha x_{t i}+\beta y_{t i}+\delta_{z_{t i}}+\varepsilon_{t i}
$$

where $k_{t i}$ is the real per capita level of earmarks in year $t$ in state $i ; x_{t i}$ is a vector of state-level demographic and economic variables including population and real per capita income; $y_{t i}$ is a vector of political variables including the number of Republican Senators in the state, the

percentage of Republican members of the House of Representatives as a percent of the total state delegation, the length of service of the state's junior and senior Senators, and whether the state is a traditional "swing state" defined as a state in which the winning margin in the 2004 presidential vote was $5 \%$ or less; $z_{t i}$ is a vector of dummy variables for the 7 years of observations in the dataset and for the 9 census regions; $\gamma$ is a constant, and $\varepsilon_{t i}$ is a random error term.

\section{Results}

As shown in Table 2, small states (in terms of population) earn a disproportionately large share of Congressional earmarks. As noted by Hauk and Wacziarg (2007), this is almost certainly due to the Constitutional compromise that awarded each state two Senators regardless of size while allocating representation the House according to population. State per capita income levels did not affect earmarking.

In terms of the political explanatory variables, the presence of a Republican Congressional delegation increases pork spending in the state. Each Republican Senator in a state increases earmarks by about $\$ 30$ per capita, and a 10 percentage point increase in the proportion 
of Republicans in a state's House delegation increases per capita earmarks by $\$ 5.68$. As the average state has roughly 9 House members, this translates into an increase of roughly $\$ 6$ per capita for every Republican House member in an average state. Traditionally, Republicans have been the defenders of small government, but in recent years have increasingly come under criticism for abandoning these principles, and the data bear out this criticism. It should be noted, however, that it is not possible to disentangle the spending habits of the party in power from the spending habits of the Republicans in particular since over the time period of the data the Republicans controlled both the House and the Senate during all but a 6 month period following the defection of Vermont senator Jim Jeffords from the Republican Party to the Democrats in 2002.

Contrary to what might have been predicted, Congress does not seem to lavish swing states with largess in order to buy their votes. In fact, swing states experience lower earmarks at a statistically significant level. If states that experience close votes in Presidential elections are not the same states that experience close votes in Senate or House elections, however, this result may not come as a surprise.

The most noteworthy political variable is the tenure of the state's senior Senator, confirming the hypothesis of Bernhardt, et al. (2004). For every year of experience in the Senate of a state's more senior Senator, the per capita earmarks received by that state's residents increase by $\$ 4.48$. Thus, as an example, when John Thune defeated 18-year incumbent Senator Tom Daschle for his South Dakota Senate seat in the 2004 election, the residents of the state could expect a large decrease in level of earmarked funds sent their way from Washington, D.C. as a result of the state's loss of seniority in the Senate. The tenure of their senior Senator fell from Tom Daschle's 18 years to colleague Tim Johnson's 8 years, a fall of 10 years. Ceteris 
paribus, the state should expect a decrease in earmarked spending of $\$ 44.76$ per person. In fact, earmarks to South Dakota per capita fell from $\$ 116.47$ in Daschle's last year to $\$ 67.52$ in Thune's first, a decrease of $\$ 48.95$.

\section{Conclusions}

The earmarking process, through which House and Senate members can circumvent the standard federal budgeting process, provides an easy avenue through which funds can be allocated to a lawmaker's home district. Our analysis of Congressional earmarks from 20002006 finds that on average smaller states receive the largest amount of per capita earmarked funding, most likely as a result of their disproportionate influence in the Senate. In addition, the presence of a Republican Congressional delegation, the party in power over the time period of the study, increases pork spending in the state. Finally, the tenure of a state's senior Senator has a large effect on the state's receipt of earmarked funds.

Reform of the earmarking system is a difficult problem to tackle, as the defeat of the proposed earmark moratorium in early 2008 attests. Legislators wield their influence earned through seniority and party control to direct federal spending to their constituents. This cozy arrangement benefits residents of states with low populations and senior politicians, and these voters reciprocate by reelecting incumbents by wide margins. This arrangement does little, however, to ensure the efficiency of government spending. Indeed, the Gravina Island bridge is unlikely to be the last "bridge to nowhere." 


\section{REFERENCES}

Alverez, R. Michael, and Jason L. Saving (1997). "Congressional Committees and the Political Economy of Federal Outlays," Public Choice, Vol. 92:1-2, 55-73.

Bernhardt, Dan, Sangita Dubey, and Eric Hughson (2004), “Term Limits and Pork Barrel Politics," Journal of Public Economics, Vol. 88:12, 2383-2422.

Citizens Against Government Waste (2006). "Congressional Pig Book Summary," http://www.cagw.org/, published April 5, 2006, accessed May 15, 2008.

Cooper, Michael (2008). “Tax Cuts at Center of McCain's Economic Plan,” New York Times, April 16, 2008.

Hauk, William R, Jr. and Romain Wacziarg (2007). “Small States, Big Pork,” Quarterly Journal of Political Science, Vol. 2:1, 95-106.

Knight, Brian (2004). "Legislative Representation, Bargaining Power, and the Distribution of Federal Funds: Evidence from the U.S. Senate," National Bureau of Economic Research, No. 10385 . 
Table 1 Summary Statistics by Year

\begin{tabular}{|c|c|c|c|c|c|c|c|}
\hline & 2000 & 2001 & 2002 & 2003 & 2004 & 2005 & 2006 \\
\hline $\begin{array}{l}\text { Earmarks } \\
\text { Per Capita }\end{array}$ & $\begin{array}{l}63.11 \\
(120.27)\end{array}$ & $\begin{array}{l}71.93 \\
(146.68)\end{array}$ & $\begin{array}{l}80.61 \\
(131.23)\end{array}$ & $\begin{array}{l}77.13 \\
(109.18)\end{array}$ & $\begin{array}{l}74.66 \\
(140.09)\end{array}$ & $\begin{array}{l}83.57 \\
(162.10)\end{array}$ & $\begin{array}{l}59.11 \\
(88.63)\end{array}$ \\
\hline Population & $\begin{array}{l}5632450 \\
(6206618)\end{array}$ & $\begin{array}{l}5690688 \\
(6291343)\end{array}$ & $\begin{array}{l}5746177 \\
(6366926)\end{array}$ & $\begin{array}{l}5797404 \\
(6438034)\end{array}$ & $\begin{array}{l}5852238 \\
(6505603)\end{array}$ & $\begin{array}{l}5906277 \\
(6565170)\end{array}$ & $\begin{array}{l}5963387 \\
(6633559)\end{array}$ \\
\hline $\begin{array}{l}\text { Income Per } \\
\text { Capita }\end{array}$ & $\begin{array}{l}35706.91 \\
(5560.95)\end{array}$ & $\begin{array}{l}35853.25 \\
(5362.46)\end{array}$ & $\begin{array}{l}35739.73 \\
(5170.56)\end{array}$ & $\begin{array}{l}35855.93 \\
(5018.25)\end{array}$ & $\begin{array}{l}36731.98 \\
(5244.91)\end{array}$ & $\begin{array}{l}37170.37 \\
(5444.13)\end{array}$ & $\begin{array}{l}38027.42 \\
(5549.60)\end{array}$ \\
\hline $\begin{array}{l}\text { Number } \\
\text { Republican } \\
\text { Senators }\end{array}$ & $\begin{array}{l}1.08 \\
(.804)\end{array}$ & $\begin{array}{l}1.08 \\
(.804)\end{array}$ & $\begin{array}{l}1.02 \\
(.869)\end{array}$ & $\begin{array}{l}1.02 \\
(.869)\end{array}$ & $\begin{array}{l}1.06 \\
(.867)\end{array}$ & $\begin{array}{l}1.06 \\
(.867)\end{array}$ & $\begin{array}{l}1.14 \\
(.857)\end{array}$ \\
\hline $\begin{array}{l}\text { Tenure of } \\
\text { Junior } \\
\text { Senator }\end{array}$ & $\begin{array}{l}7.44 \\
(6.73)\end{array}$ & $\begin{array}{l}8.34 \\
(6.81)\end{array}$ & $\begin{array}{l}7.34 \\
(6.88)\end{array}$ & $\begin{array}{l}8.16 \\
(6.95)\end{array}$ & $\begin{array}{l}7.34 \\
(5.76)\end{array}$ & $\begin{array}{l}8.34 \\
(5.76)\end{array}$ & $\begin{array}{l}8.32 \\
(6.46)\end{array}$ \\
\hline $\begin{array}{l}\text { Tenure of } \\
\text { Senior } \\
\text { Senator }\end{array}$ & $\begin{array}{l}17.04 \\
(10.08)\end{array}$ & $\begin{array}{l}17.56 \\
(10.33)\end{array}$ & $\begin{array}{l}17.42 \\
(10.82)\end{array}$ & $\begin{array}{l}18.26 \\
(10.89)\end{array}$ & $\begin{array}{l}18.42 \\
(10.72)\end{array}$ & $\begin{array}{l}19.42 \\
(10.72)\end{array}$ & $\begin{array}{l}18.52 \\
(11.26)\end{array}$ \\
\hline $\begin{array}{l}\text { Proportion } \\
\text { House Reps. } \\
\text { Republican }\end{array}$ & $\begin{array}{l}.558 \\
(.318)\end{array}$ & $\begin{array}{l}.558 \\
(.318)\end{array}$ & $\begin{array}{l}.558 \\
(.300)\end{array}$ & $\begin{array}{l}.5616 \\
(.301)\end{array}$ & $\begin{array}{l}.548 \\
(.304)\end{array}$ & $\begin{array}{l}.565 \\
(.299)\end{array}$ & $\begin{array}{l}.551 \\
(.306)\end{array}$ \\
\hline Swing State & .24 & .24 & .24 & .24 & .24 & .24 & .24 \\
\hline Observations & 50 & 50 & 50 & 50 & 50 & 50 & 50 \\
\hline
\end{tabular}

Standard deviation reported in parentheses where applicable. Dollar values are adjusted to 2008 dollars. "Swing State" is a dummy indicating a margin of victory of less than $5 \%$ in the 2004 Presidential election. 


\section{Table 2 Determinants of State Earmarks Per Capita}

\begin{tabular}{lc}
\hline & Earmarks Per Capita \\
\hline Population & $-0.000006^{* *}$ \\
& $(0.0000009)$ \\
Income Per Capita & 0.00013 \\
& $(0.0013)$ \\
Number Republican Senators & $29.9336^{* *}$ \\
& $(7.6327)$ \\
Tenure of Junior Senator & -0.2499 \\
& $(1.0728)$ \\
Tenure of Senior Senator & $4.4757^{* *}$ \\
Proportion House Reps. Republican & $(0.6898)$ \\
& $56.7883^{* *}$ \\
Swing State & $(20.9291)$ \\
& $-24.3295+$ \\
Observations & $(12.6507)$ \\
R-squared & 350 \\
\hline
\end{tabular}

Results from estimating equation 1 using Ordinary Least Squares. Standard errors are reported in parentheses.

Dollar values are adjusted to 2008 dollars. "Swing State" is a dummy indicating a margin of victory of

less than 5\% in the 2004 Presidential election. Model also includes year and Census division indicators which are omitted for brevity. Full results available from the authors upon request.

+ significant at $10 \% ; *$ significant at $5 \% ; * *$ significant at $1 \%$ 